Research Article

\title{
Numerical Modeling and Optimization of Lead-Free Hybrid Double Perovskite Solar Cell by Using SCAPS-1D
}

\author{
Syed Sajjad Hussain ${ }^{(D)},{ }^{1}$ Saira Riaz, ${ }^{1}$ Ghazi Aman Nowsherwan, ${ }^{1}$ Khizer Jahangir, ${ }^{1}$ \\ Akram Raza, ${ }^{1}$ Muhammad Javaid Iqbal, ${ }^{1}$ Imran Sadiq, Syed Mutahir Hussain, \\ and Shahzad Naseem ${ }^{1}$ \\ ${ }^{1}$ Centre of Excellence in Solid State Physics, University of the Punjab, Lahore 54590, Pakistan \\ ${ }^{2}$ National College of Business Administration \& Economics, 40-E1, Gulberg III, Lahore, Pakistan \\ Correspondence should be addressed to Syed Sajjad Hussain; sajjadh.cssp@pu.edu.pk
}

Received 7 October 2020; Accepted 8 July 2021; Published 17 July 2021

Academic Editor: Jayanta Mondol

Copyright (c) 2021 Syed Sajjad Hussain et al. This is an open access article distributed under the Creative Commons Attribution License, which permits unrestricted use, distribution, and reproduction in any medium, provided the original work is properly cited.

\begin{abstract}
The highest power conversion efficiency (PCE) for organic-inorganic perovskite solar cells based on lead is reported as $25.2 \%$ in 2019. Lead-based hybrid perovskite materials are used in several photovoltaics applications, but these are not highly favored due to the toxicity of lead and volatility of organic cations. On the other hand, hybrid lead-free double perovskite has no such harm. In this research study, SCAPS numerical simulation is utilized to evaluate and compare the results of perovskite solar cell based on double perovskite $(\mathrm{FA})_{2} \mathrm{BiCuI}_{6}$ and standard perovskite $\mathrm{CH}_{3} \mathrm{NH}_{3} \mathrm{PbI}_{3}$ as an active layer. The results show that the power conversion efficiency obtained in the case of $(\mathrm{FA})_{2} \mathrm{BiCuI}_{6}$ is $24.98 \%$, while in the case of $\mathrm{CH}_{3} \mathrm{NH}_{3} \mathrm{PbI}_{3}$, it is reported as $26.42 \%$. This indicates that the hybrid organic-inorganic double perovskite (FA) ${ }_{2} \mathrm{BiCuI}_{6}$ has the ability to replace hybrid organic-inorganic perovskite $\mathrm{CH}_{3} \mathrm{NH}_{3} \mathrm{PbI}_{3}$ to expand next-generation lead-free harmless materials for solar cell applications.
\end{abstract}

\section{Introduction}

A perovskite solar cell (PSC) incorporates a perovskite material whose configuration and crystallographic structure is the same as the perovskite mineral. In single intersection designs, power conversion efficiencies of solar cells utilizing these materials expanded from $\sim 3.8 \%$ in 2009 to $\sim 25.2 \%$ in 2019. Perovskite solar cells along these lines present the quickest progressing solar-powered innovation. Considerably, superior efficiencies and low-generation expenses make hybrid perovskite solar cells industrially appealing. This innovation of hybrid organic-inorganic PSCs has seen a rapid movement, and each time, the new level of power conversion efficiency had been achieved.

Perovskite materials have been noticeable for a long time. But in 2009, A. Kojima et al. presented the first design of a solar cell which was organic metallic perovskites $\left(\mathrm{CH}_{3} \mathrm{NH}_{3} \mathrm{PbBr}_{3}\right.$ and $\left.\mathrm{CH}_{3} \mathrm{NH}_{3} \mathrm{PbI}_{3}\right)$ into dye-sensitized solar cells (DSSCs) and achieved efficiencies up to 3.13\% and 3.8\% [1]. A perovskite cell of size 2-3 nm nanocrystal has achieved productivity (PCE) of $6.54 \%$ after two years in 2011 [2]. Later on, Johnston and Sanith et al. created a planar heterojunction perovskite solar cell with the electron transport layer of minimized $\mathrm{TiO}_{2}$ film rather than scaffold $\mathrm{TiO}_{2}$. These thin-film-like solar cells boost the efficiency up to $15.4 \%$ [3]. During the year 2013, energy conversion efficiencies arrived at a dumbfounding of $16.2 \%$ [4]. Around the same time, tuning of $\mathrm{TiO}_{2}$ layer treatment yields energy conversion efficiency (PCE) of 19.3\% [5] as it offered superior electrical and optical properties [6]. While spiroMeOTAD as HTM-based PSCs has attained the efficiency from $6 \%$ to almost $20 \%[7,8], \mathrm{ZnO}$ as ETM-based PSCs has attained maximum efficiency (PCE) of $15.7 \%$, which is comparable to $\mathrm{TiO}_{2}$ and can be used as its alternative [9]. In 2017, Korean researchers Y.WS and N. JH et al. reported the maximum efficiency (PCE) of $20.1 \%$ [10]. While the 
perovskite solar cells (PSCs) performance enhanced quickly from the last decade by numerous researchers, still the efficiencies of perovskite solar cells have not surpassed the maximum theoretical limit of Shockley-Queisser, which was around $31.4 \%[11,12]$. At that point, various scientists were working on lead-based perovskite solar cells and presented different strategies to achieve superior performance and high outcomes.

SCAPS-1D is utilized intensively investigating thin-film solar cells throughout the years for modeling of thickness of layered structures and to examine the outcome of device design and materials parameters on their photovoltaic performance. Kai Tan et al. designed solid-state PSCs with SCAPS-1D. They reported that the function of the preferred hole transport material (HTM) candidate on the outcome of solar cells with a group of copper conductors (CuI) and thiophene polymer (PTAA) reached PCE relatively higher because of their high bandgap, large conductivity, and superior chemical interaction with a perovskite absorber [13]. Lin et al. structured the HTM-free perovskite solar cell by a SCAPS device simulator and achieved PCE over 15\% under fair conditions [14]. Narender et al. had simulated electrically organic solar cells at different charge carrier mobilities. They conducted a maximum efficiency of the organic solar cell at maximum short circuit current at the electron and hole mobility of $0.510 \times 10^{-6} \mathrm{~m}^{2} \mathrm{v}^{-1} \mathrm{~s}^{-1}$ [15]. Usha et al. designed the organic-inorganic PSC by using the SCAPS-1D device simulator and investigated the effect of active layer thickness and defect density on the outcome of the solar cell and got the power conversion efficiency (PCE) of $31.77 \%$ and maximum current density (Jsc) value of $\sim 25.60 \mathrm{~mA} \mathrm{~cm}{ }^{-2}$ [16]. Afterward, Zulqarnain Haider et al. studied the leadbased organic-inorganic PSC with the hole transport material (HTM) as CuI by simulation program SCAPS. They analyzed that $\mathrm{CuI}$ as an alternate HTM can be used with $\mathrm{CH}_{3} \mathrm{NH}_{3} \mathrm{PbI}_{3}$ and can substitute spiro-MeOTAD, which is expensive HTM for lead-based organic-inorganic PSC [17]. Abdel Hadi et al. analyzed the lead-based perovskite solar cells with different parameters by using SCAPS-1D. They studied that the optimized performance can be achieved by varying thickness and doping levels of the active material and attained the energy conversion of this solar cell up to $30.15 \%$ [18]. Enebe et al. showed the effect of annealing of nanostructured $\mathrm{CuO} / \mathrm{TiO}_{2}$ heterojunction solar cells and interpreted that, with an annealed sample within the range of $300 \mathrm{~K}-423.15 \mathrm{~K}$, the change in the efficiency of the solar cell is quite significant [19].

The significant problems that perovskite solar cells face are stability and toxicity. The instability of PSCs is mainly concerned with the ecological effects. However, PSCs are still away from industrialized purposes as a clean, renewable energy source because it contains lead as the prime material for absorbing sunlight, which is a harmful material for the environment. Pollution of lead can cause long-term ecological damage due to high degradation time and high toxicity. In this research article, the organic cation is replaced by formamidinium (FA) $[20,21]$, which is the strongest candidate to replace methylammonium (MA) in PSCs, and the inorganic cation is replaced with bismuth (Bi) while lead $(\mathrm{Pb})$ is replaced by the copper $(\mathrm{Cu})$ to avoid instability and toxicity issues. We analyzed and compared the performance of the device with a standard lead-based hybrid PSC by the SCAPS device simulator, which is developed at the University of Gent [22].

\section{Device Modeling and Simulation}

2.1. Methodology and Modeling. The device modeling and simulation in the accompanying segments were executed by SCAPS (version 3.3.07). The program composed of various panels by which the user can optimize the parameters and determine outcomes. Figure 1 shows the step-by-step simulation procedure for the SCAPS program.

It is based on coupled continuity differential equations and Poisson's differential equation for electrons and holes. The fundamental theory of this program is to solve continuity differential equations and Poisson's differential equation by numerical differentiation and the Gummel type iteration method $[22,23]$.

$$
\begin{aligned}
\frac{\mathrm{d} p_{n}}{\mathrm{~d} t} & =G_{p}-\frac{p_{n}-p_{n 0}}{\tau_{p}}-p_{n} u_{p} \frac{\mathrm{d} E}{\mathrm{~d} x}-u_{p} E \frac{\mathrm{d} p_{n}}{\mathrm{~d} x}+D_{p} \frac{\mathrm{d}^{2} p_{n}}{\mathrm{~d} x^{2}}, \\
\frac{\mathrm{d} n_{p}}{\mathrm{~d} t} & =G_{n}-\frac{n_{p}-n_{p 0}}{\tau_{n}}-n_{p} u_{n} \frac{\mathrm{d} E}{\mathrm{~d} x}-u_{n} E \frac{\mathrm{d} n_{p}}{\mathrm{~d} x}+D_{p} \frac{\mathrm{d}^{2} n_{p}}{\mathrm{~d} x^{2}} \\
\frac{\mathrm{d}}{\mathrm{d} x}\left(\varepsilon(x) \frac{\mathrm{d} \phi}{\mathrm{d} x}\right) & =q\left[p(x)-n(x)+N_{d^{+}}(x)-N_{a^{-}}(x)+p_{t}(x)-n_{t}(x)\right],
\end{aligned}
$$

where $\varepsilon$ represents the dielectric permittivity, $q$ represents the electron charge, $G$ represents the rate of generation, $D$ represents the diffusion coefficient, $\varphi$ represents the electrostatic potential, $E$ represents the electric field, $p(x)$ represents the free holes, $n(x)$ represents the free electrons, $p_{t}(x)$ represents the trapped holes, $n_{t}(x)$ represents the trapped electrons, $N_{d+}$ represents the donor ionized doping concentration, $N_{a-}$ represents the acceptor ionized doping concentration, and $x$ represents the thickness. 


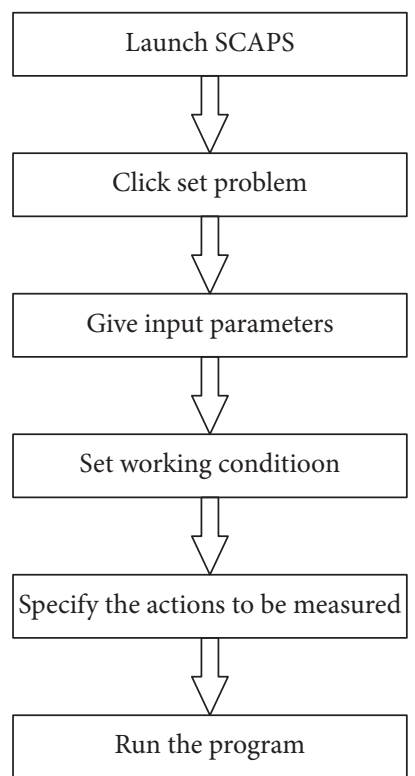

FIgURE 1: Simulation procedure for SCAPS-1D.

The adopted planar heterojunction structure is a characteristic perovskite solar cell structure. The cell consists of an absorber layer $(\mathrm{FA})_{2} \mathrm{BiCuI}_{6}$, hole transport layer (spiroMeOTAD $\quad\left(2,2^{\prime}, 7,7^{\prime}\right.$-tetrakis[N,N-di(4-methoxyphenyl) amino]-9, $9^{\prime}$-spirobifluorene), electron transport layer $\left(\mathrm{TiO}_{2}\right)$, fluorine doped tin oxide layer (FTO), and gold (Au) as shown in Figure 2.

2.2. Device Simulation Parameters. All parameters used in simulations for every layer in the structure are derived from the literature reported in $[13,14,24-37]$. The individual materials parameters for spiro-MeOTAD, $(\mathrm{FA})_{2} \mathrm{BiCuI}_{6}$, $\mathrm{TiO}_{2}$, and FTO have to go through in terms of donor density (NA), acceptor density (ND), electron mobility $\left(u_{n}\right)$, hole mobility $\left(u_{p}\right)$, dielectric permittivity $(\varepsilon)$, bandgap (Eg), and electron affinity $(x)$. All the major simulation parameters are elaborated in Tables 1 and 2 .

2.3. Device Model Validation. SCAPS-1D simulation software validity is confirmed by reported literature [13, 38-42], which compared device performance from real-world experimental characterization with theoretical results obtained from the software. Moreover, the simulated values of device performance parameters are highly close to the experimental results published in the replicated literature. Therefore, SCAPS-1D software is an effective modeling tool in designing and analyzing various high-performance solar cells, including perovskite, CIGS, CdTe, CZTS, and others [43-48]. As a result, it can certify the practicality and availability of device configurations and material values to a certain extent.

Other parameters of materials such as electron and hole thermal velocity are both set as $10^{7} \mathrm{~cm} / \mathrm{s}$ respectively, whereas the effective density of state for valence and conduction band is $1.8 \times 10^{18}$ and $2 \times 10^{18} \mathrm{~cm}^{-3}$. The

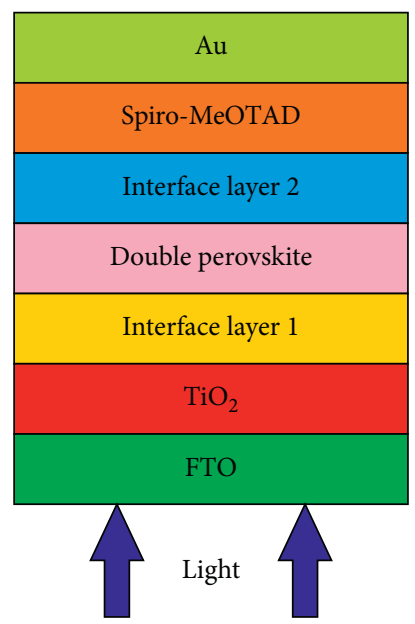

Figure 2: Schematic representation of device architecture.

absorption coefficient data have been taken from different works of literature to make things easier for device simulation [35, 49-51] (Supplementary Materials). The spectrum used in device simulation is AM1.5 G, and the operating temperature is set at $300 \mathrm{~K}$. Furthermore, the working point, including numerical setting, has been set to default values. The scanning voltage is set as $\mathrm{V} 1=0 \mathrm{~V}$ to $\mathrm{V} 2=1.2 \mathrm{~V}$. All the simulations in this software run under these settings.

\section{Results and Discussion}

3.1. Comparison between Perovskite $\left(\mathrm{CH}_{3} \mathrm{NH}_{3} \mathrm{PbI}_{3}\right)$ and Double Perovskite $(\mathrm{FA})_{2} \mathrm{BiCuI}_{6}$. Lead-based metallic perovskite solar cells are associated with instability and toxicity issues. On the other side, lead-free double PSC has no such issues. Lead-free organic-inorganic double perovskite has drawn considerable concern for solar cells and other optoelectronic properties. We had taken the copper-based perovskite material $(\mathrm{FA})_{2} \mathrm{BiCuI}_{6}$ which is an indirect bandgap semiconductor having a bandgap value of $1.55 \mathrm{eV}$, which is comparable to the bandgap value of perovskite $\mathrm{CH}_{3} \mathrm{NH}_{3} \mathrm{PbI}_{3}$. The dielectric constant of copper-based double perovskite is 5.27, while the dielectric constant of lead-based perovskite is 6.3. More particularly, copper-based double perovskite has finer optoelectronic properties due to its high extinction coefficient, large optical conductivity, and potential dielectric properties.

The numerical study and comparison are performed on organic-inorganic perovskite and copper-based double organic-inorganic perovskite. From the simulation, it is found that in the case of $(\mathrm{FA})_{2} \mathrm{BiCuI}_{6}$, the output parameters short-circuit current density (Jsc), open-circuit voltage (Voc), power conversion efficiency (PCE), and fill factor (\% FF) at absorber layer thickness $300 \mathrm{~nm}$ is $32.95 \mathrm{~mA} / \mathrm{cm}^{2}$, $0.94 \mathrm{~V}, 24.98 \%$, and $80.73 \%$, while in the case of $\mathrm{CH}_{3} \mathrm{NH}_{3} \mathrm{PbI}_{3}$, these (Jsc, Voc, PCE, and $\mathrm{FF}$ ) are $34.96 \mathrm{~mA}$ / $\mathrm{cm}^{2}, 0.94 \mathrm{~V}, 26.43$, and $80.39 \%$, respectively. Furthermore, the J-V and PCE curves of their comparison are shown in Figure 3 . This clearly shows that there is a very slight difference in values of Jsc, but both curves end at the same 
TABLE 1: Material parameters set in simulation.

\begin{tabular}{|c|c|c|c|c|c|}
\hline Parameters & FTO & $\mathrm{TiO}_{2}$ & $\left(\mathrm{CH}_{3} \mathrm{NH}_{3} \mathrm{PbI}_{3}\right)$ & $(\mathrm{FA})_{2} \mathrm{BiCuI}_{6}$ & Spiro-MeOTAD \\
\hline Thickness (nm) & 200 & 50 & 200 & 200 & 150 \\
\hline Acceptor density $\left(\mathrm{cm}^{-3}\right)$ & 0 & 0 & 0 & 0 & $10^{18}$ \\
\hline Donor density $\left(\mathrm{cm}^{-3}\right)$ & $10^{19}$ & $10^{17}$ & $10^{13}$ & $10^{13}$ & 0 \\
\hline Bandgap $(\mathrm{eV})$ & 3.5 & 3.2 & 1.55 & 1.55 & 2.9 \\
\hline Relative dielectric permittivity & 9 & 10 & 6.3 & 5.27 & 3 \\
\hline Mobility of electron & 20 & 20 & 2 & 2 & $10^{-4}$ \\
\hline Mobility of hole & 10 & 10 & 1 & 1 & $10^{-4}$ \\
\hline Electron affinity $(\mathrm{eV})$ & 4 & 4.2 & 3.7 & 3.7 & 2.2 \\
\hline Defect density $\left(\mathrm{cm}^{-3}\right)$ & $10^{15}$ & $10^{15}$ & & $2.5 \times 10^{13}$ & $10^{15}$ \\
\hline
\end{tabular}

TABle 2: Device parameters set in the simulation.

\begin{tabular}{ll}
\hline Interface defect density & \\
\hline IL1 (TiO $/$ pero) defect density & $10^{15} \mathrm{~cm}^{-3}$ \\
IL2 (pero/spiro) defect density & $10^{15} \mathrm{~cm}^{-3}$ \\
\hline Back metal contact properties & $-5.1 \mathrm{eV}$ \\
The electron work function of Au & $10^{5} \mathrm{~cm} / \mathrm{s}$ \\
Surface recombination velocity of the electron & $10^{7} \mathrm{~cm} / \mathrm{s}$ \\
Surface recombination velocity of hole & \\
\hline Front metal contact properties & $-4.4 \mathrm{eV}$ \\
The electron work function of TCO & $10^{7} \mathrm{~cm} / \mathrm{s}$ \\
Surface recombination velocity of the electron & $10^{5} \mathrm{~cm} / \mathrm{s}$ \\
Surface recombination velocity of hole
\end{tabular}

point, which indicates both active layers have the same value of Voc. As both materials have high optical properties, both exhibit high power conversion efficiency values, but double perovskite has no stability and toxicity problems like perovskite.

The numerical analysis on lead-based perovskite and leadfree double perovskite solar cells is also compared with experimental data indicated in Table 3. Simulated device performance parameters are found to be quite close to experimental results published in the scientific literature. This study also gives theoretical guidance towards the efficient realization of perovskite solar cells by optimizing their parameters.

Results signify that lead-free double perovskite is a potential alternative to lead-based perovskite, which can be used to manufacture next-generation organic-inorganic PSC and can evade instability and stability issues linked with lead-based perovskites.

3.2. Influence of Absorber Layer Thickness. The absorber layer of the perovskite solar cell plays an essential role in device performance and outcome. Therefore, the variation can considerably affect the performance and outcome of a solar cell in the thickness of an active layer of a solar cell. In this study, absorber layer thickness varies from $100 \mathrm{~nm}$ to $1000 \mathrm{~nm}$, and we observed the effect on output parameters while all other parameters are set constant.

Figure 4 and Table 4 show the deviation in device outcomes with the thickness of the active layer. The simulation results signify that with the increase in thickness of the active layer, short-circuit current density (Jsc) increases and approaches to the optimum value of $\sim 39 \mathrm{mAcm}^{-2}$ as shown in Figure 4(a). Excess carrier concentration increases by increasing thickness due to the absorption of light, which eventually increases Jsc values. Perovskite material has very high extinction and high conductivity, and it can attain very high values of current density (Jsc) and efficiency (PCE) as its thickness increases. In FF/thickness graph (Figure 4(b)), the fill factor constantly drops from $83.60 \%$ to $67.28 \%$ by changing thickness from $100 \mathrm{~nm}$ to $1000 \mathrm{~nm}$. Fill factor is measured as the capability of a device to transfer maximum obtainable power to the generated electrical load. The decrease in the fill factor value with the increase in thickness is due to internal power depletion build-up, which leads to a decrease in the fill factor.

In Voc/thickness graph (Figure 4(c)), Voc increases with the increasing thickness due to low electron-hole recombination and high generation rate. If we increase the thickness more, the recombination rate balances the generation rate, and Voc will remain the same. On the other hand, more increase in thickness leads to a decrease in Voc due to a high recombination rate and low generation rate. Voc increases to the maximum value of $\sim 0.95 \mathrm{~V}$ with the increase in thickness.

Voc can be explained by the following equation:

$$
V_{o c}=\frac{n k t}{q} \ln \left(\frac{I_{l}}{I_{0}}+1\right),
$$

where " $n$ " is a factor, $(k t / q)$ is a thermal voltage, " $I$ " represents the current produced by light, and " $I_{0}$ " represents the dark saturation current.

In PCE/thickness graph (Figure 4(d)), device efficiency (PCE) reaches the utmost point at $26.50 \%$ at $600 \mathrm{~nm}$ and then drops rapidly with the further increase in thickness. The optimal absorber thickness range lies between 400 and $700 \mathrm{~nm}$ to achieve the high PCE. As the absorber thickness exceeds the optimal value $(600 \mathrm{~nm})$, energy conversion efficiency decreases due to the high recombination rate.

3.3. Influence of Interface Defect Density $\left(N_{t}\right)$. The performance and outcome of the organic-inorganic PSC performance are highly affected by the structure and quality of the active perovskite layer. Defect density plays a key role in obtaining efficient outcomes for the device. If the quality of the film is not good, then trap density and rate of recombination of charge carriers increase, which eventually degrade the performance and outcome of the device. 


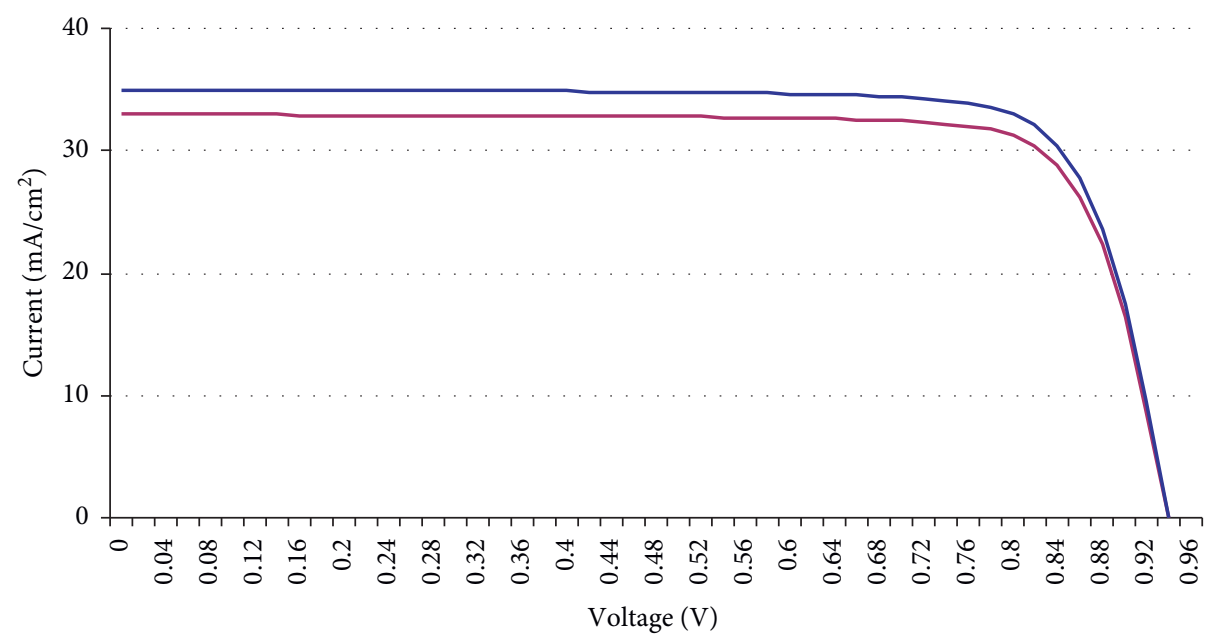

(a)

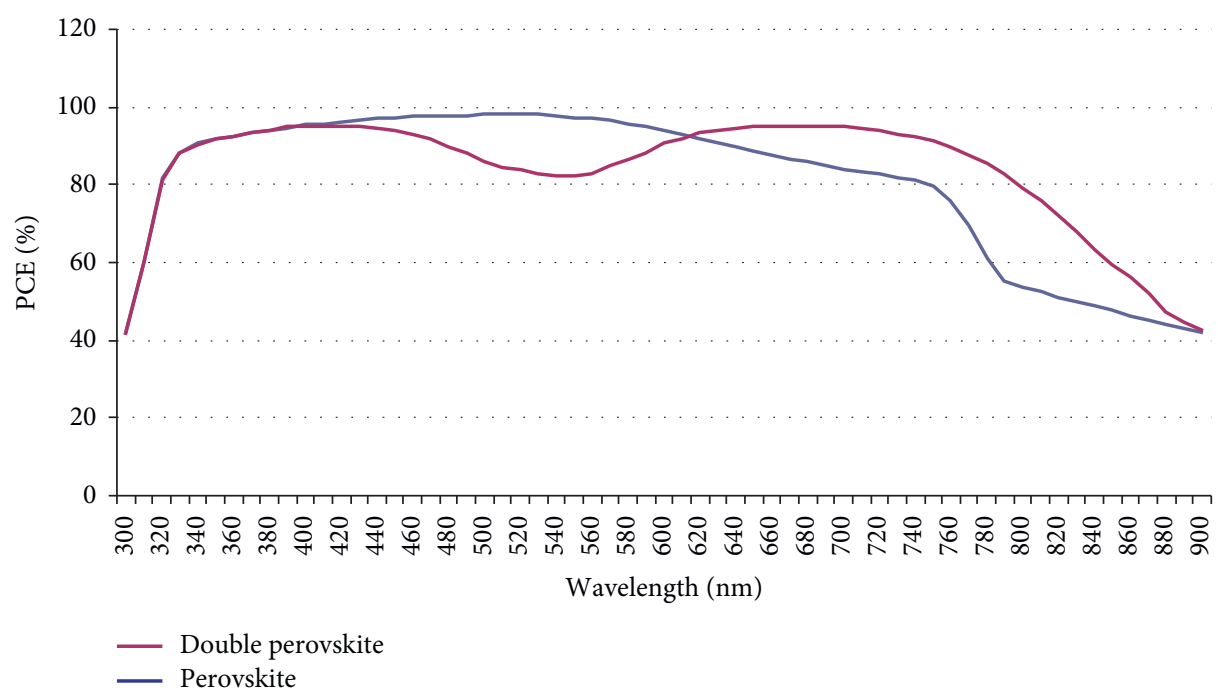

(b)

Figure 3: (a) Short-circuit current density comparison. (b) Power conversion efficiency comparison.

TABLE 3: Comparison of device parameters characterized experimentally with simulated device parameters.

\begin{tabular}{|c|c|c|}
\hline Perovskite materials & PCE $(\%)$ & Reference \\
\hline \multicolumn{3}{|l|}{ Experimental results } \\
\hline$\left(\mathrm{CH}_{3} \mathrm{NH}_{3} \mathrm{~Pb}\left(\mathrm{I}_{1-\mathrm{x}} \mathrm{Br}{ }_{\mathrm{x}}\right)_{3}\right)$ & 17.9 & {$[52]$} \\
\hline$\left(\mathrm{CH}_{3} \mathrm{NH}_{3} \mathrm{PbI}_{3}\right)$ & 19.3 & {$[53]$} \\
\hline $\mathrm{FAPBI}_{3}$ & 20.1 & {$[10]$} \\
\hline $\mathrm{Cs}^{+} / \mathrm{MA}^{+} / \mathrm{FA}-$ mixing cations & 21.1 & {$[54]$} \\
\hline Combined silicon/perovskite cells & 23.0 & {$[55]$} \\
\hline $\mathrm{CH}_{3} \mathrm{NH}_{3} \mathrm{~Pb}\left(\mathrm{I}_{3-\mathrm{x}} \mathrm{Cl}_{\mathrm{x}}\right)$ & 19.1 & {$[56]$} \\
\hline \multicolumn{3}{|l|}{ Simulation results (at thickness $200 \mathrm{~nm}$ ) } \\
\hline Spiro-MeOTAD/ $(\mathrm{FA})_{2} \mathrm{BiCuI}_{6} / \mathrm{TiO}_{2}$ & 22.40 & - \\
\hline Spiro-MeOTAD/ $\left(\mathrm{CH}_{3} \mathrm{NH}_{3} \mathrm{PbI}_{3}\right) / \mathrm{TiO}_{2}$ & 23.56 & - \\
\hline \multicolumn{3}{|l|}{ Simulation results (at thickness $300 \mathrm{~nm}$ ) } \\
\hline Spiro-MeOTAD/ $(\mathrm{FA})_{2} \mathrm{BiCuI}_{6} / \mathrm{TiO}_{2}$ & 24.98 & - \\
\hline Spiro-MeOTAD/ $\left(\mathrm{CH}_{3} \mathrm{NH}_{3} \mathrm{PbI}_{3}\right) / \mathrm{TiO}_{2}$ & 26.43 & - \\
\hline
\end{tabular}




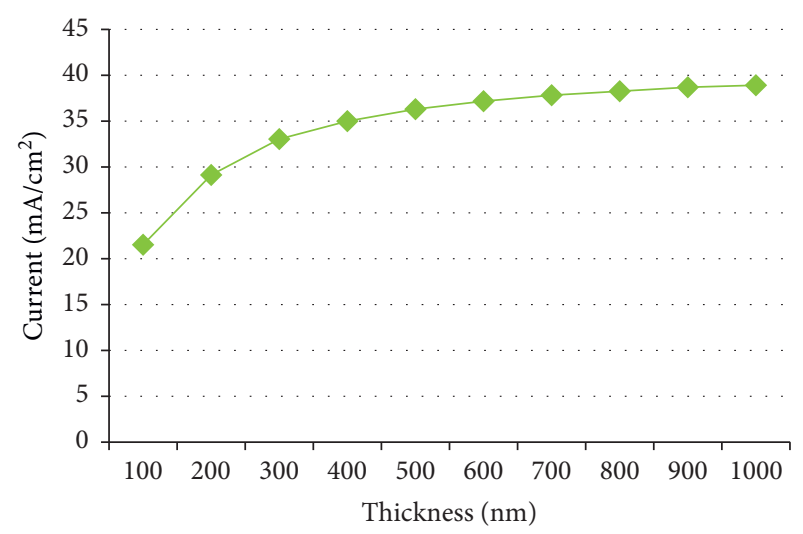

(a)

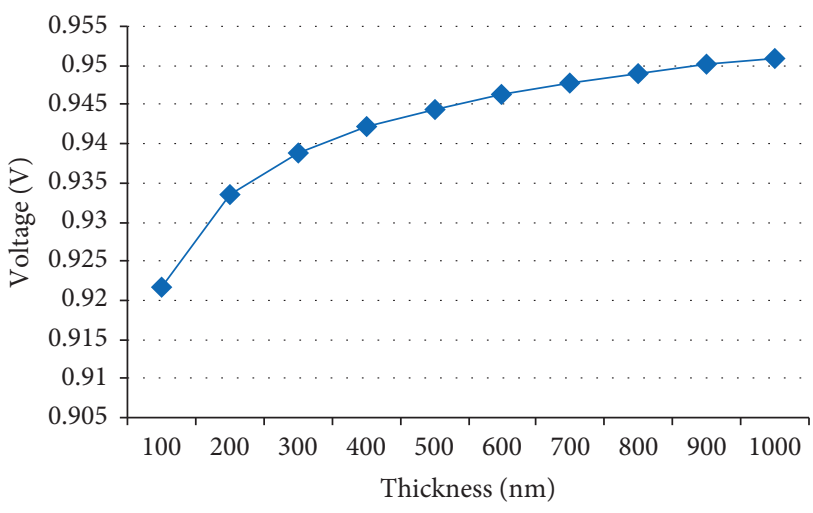

(c)

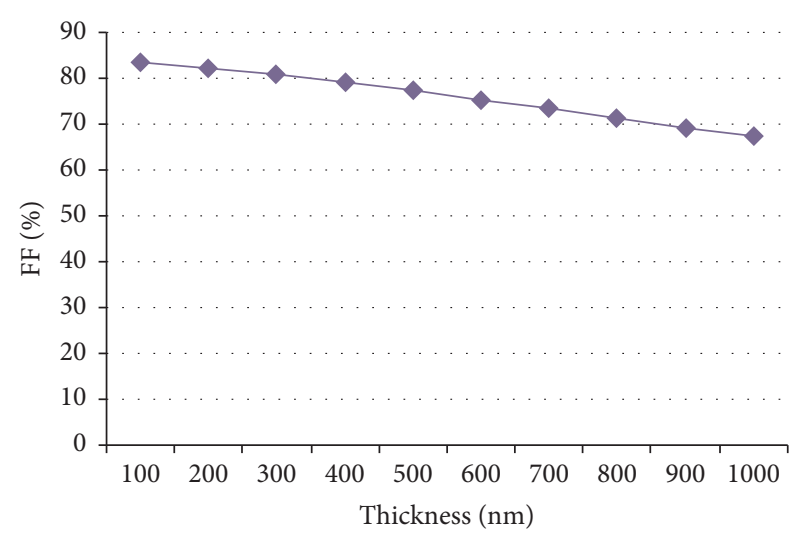

(b)

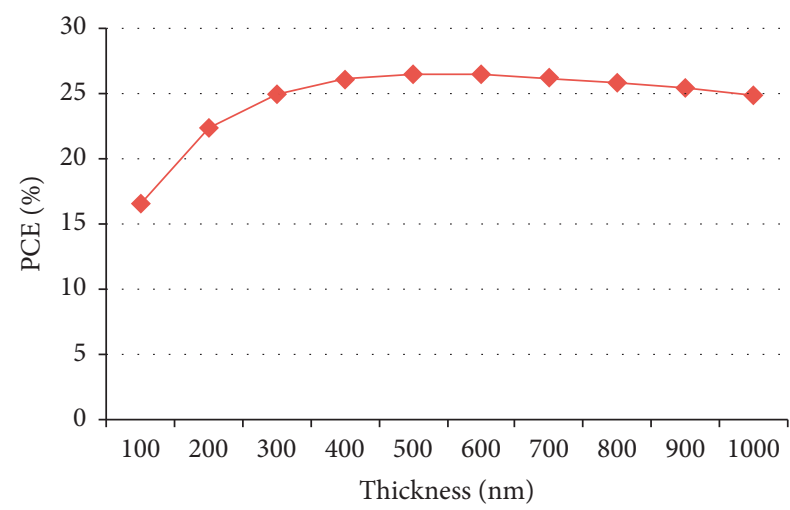

(d)

Figure 4: (a) Short-circuit current density as a function of absorber thickness. (b) Fill factor as a function of absorber thickness. (c) Opencircuit voltage as a function of absorber thickness. (d) PCE as a function of absorber thickness.

TAble 4: Device Performance at a different absorber layer thickness.

\begin{tabular}{lcccc}
\hline Thickness $(\mathrm{nm})$ & $\mathrm{V}_{\mathrm{oc}}$ (volt) & $\mathrm{FF}(\%)$ & $\mathrm{Jsc}\left(\mathrm{mA} / \mathrm{cm}^{2}\right)$ & PCE $(\%)$ \\
\hline 100 & 0.9216 & 83.60 & 21.56 & 16.61 \\
200 & 0.9335 & 82.24 & 29.18 & 22.40 \\
300 & 0.9388 & 80.73 & 32.95 & 24.98 \\
400 & 0.9421 & 79.08 & 35.03 & 26.10 \\
500 & 0.9445 & 77.28 & 36.31 & 26.50 \\
600 & 0.9463 & 75.36 & 37.16 & 26.50 \\
700 & 0.9478 & 73.39 & 37.77 & 26.28 \\
800 & 0.9491 & 71.38 & 38.23 & 25.90 \\
900 & 0.9501 & 69.34 & 38.59 & 25.42 \\
1000 & 0.9510 & 67.28 & 38.88 & 24.88 \\
\hline
\end{tabular}

In this simulation, two interface defect layers are introduced, namely, IL1 $\left(\mathrm{TiO}_{2} /(\mathrm{FA})_{2} \mathrm{BiCuI}_{6}\right)$ and IL2 $\left((\mathrm{FA})_{2} \mathrm{BiCuI}_{6} /\right.$ spiro-MeOTAD interface), to study their influence on device performance. The defect densities of the first interface layer (IL1) varied from $10^{13} \mathrm{~cm}^{-3}$ to $10^{17} \mathrm{~cm}^{-3}$ and second interface layer (IL2) varied from $10^{13} \mathrm{~cm}^{-3}$ to $10^{21} \mathrm{~cm}^{-3}$, respectively, while remaining parameters are kept at the default value.

Figures 5 and 6 show the current density-voltage (J-V) curves and power conversion efficiencies (PCEs) of double PSCs at various defect (trap) densities of $\mathrm{TiO}_{2} /(\mathrm{FA})_{2} \mathrm{BiCuI}_{6}$ and $(\mathrm{FA})_{2} \mathrm{BiCuI}_{6} /$ spiro-MeOTAD. Table 5 and Figure 7 show the deviation in perovskite solar cell (PSC) outcome parameters with different values of defect density $\left(N_{t}\right)$. It can be analyzed that the interfaces with low defect densities are favorable for device performance. Because in that case, low traps are present, and the generation rate is high. Voc and Isc increase which may lead to high PCE and FF. While on the other hand, interfaces with high defect densities cause more recombination centers and traps, which ultimately degrade the device's performance.

3.4. Influence of Carrier Mobility. The charge carrier mobility of the active layer has a significant influence on device performance. In this simulation, there are two types of charge carriers: free charge carriers (electrons and holes) and trapped charge carriers (electrons and holes). The free charge carriers have limited mobility, while the mobility of trapped charge carriers is zero, which means they cannot move. Therefore, the average mobility of charge carriers is equal to the ratio of multiplication of free charge carriers and free carrier mobility to the sum of free charge carriers and trapped charge carriers, which is elaborated in the following equation.

$$
\mu_{e}(n)=\frac{\mu_{e}^{o} n_{\text {free }}}{n_{\text {free }}+n_{\text {trap }}} .
$$




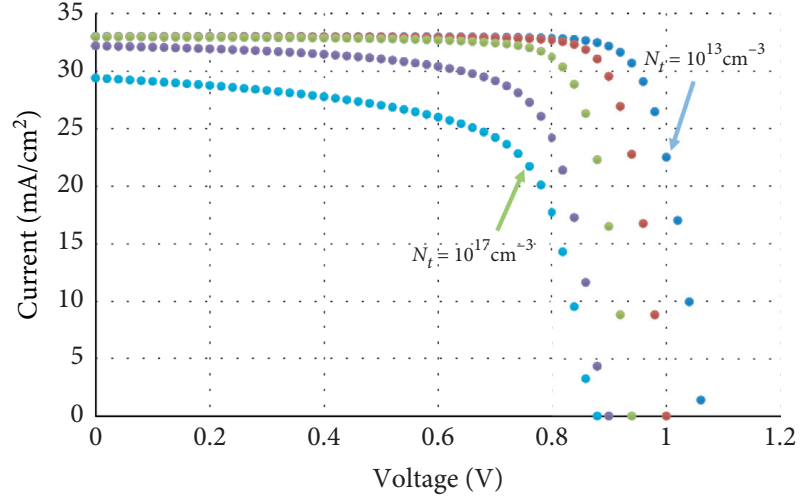

(a)

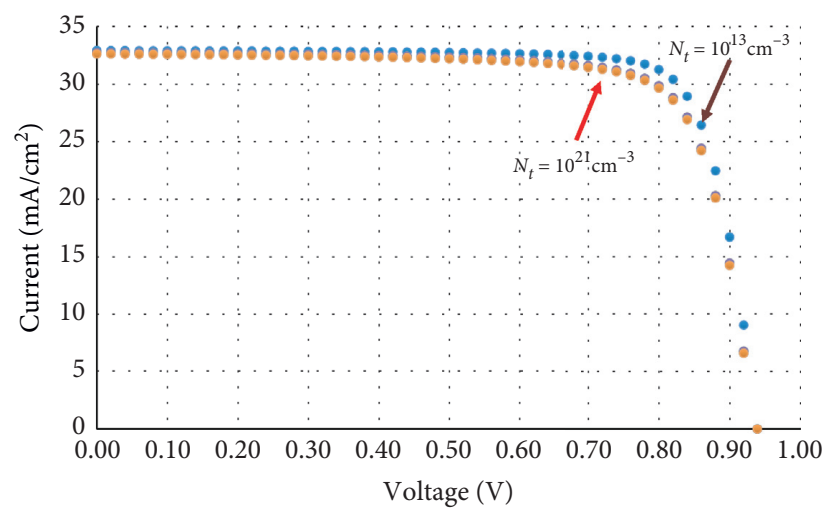

(b)

FIgURE 5: J-V curves of double PSCs with different defect densities of (a) ETM/perovskite interface IL1 and (b) perovskite/HTM interface IL2.

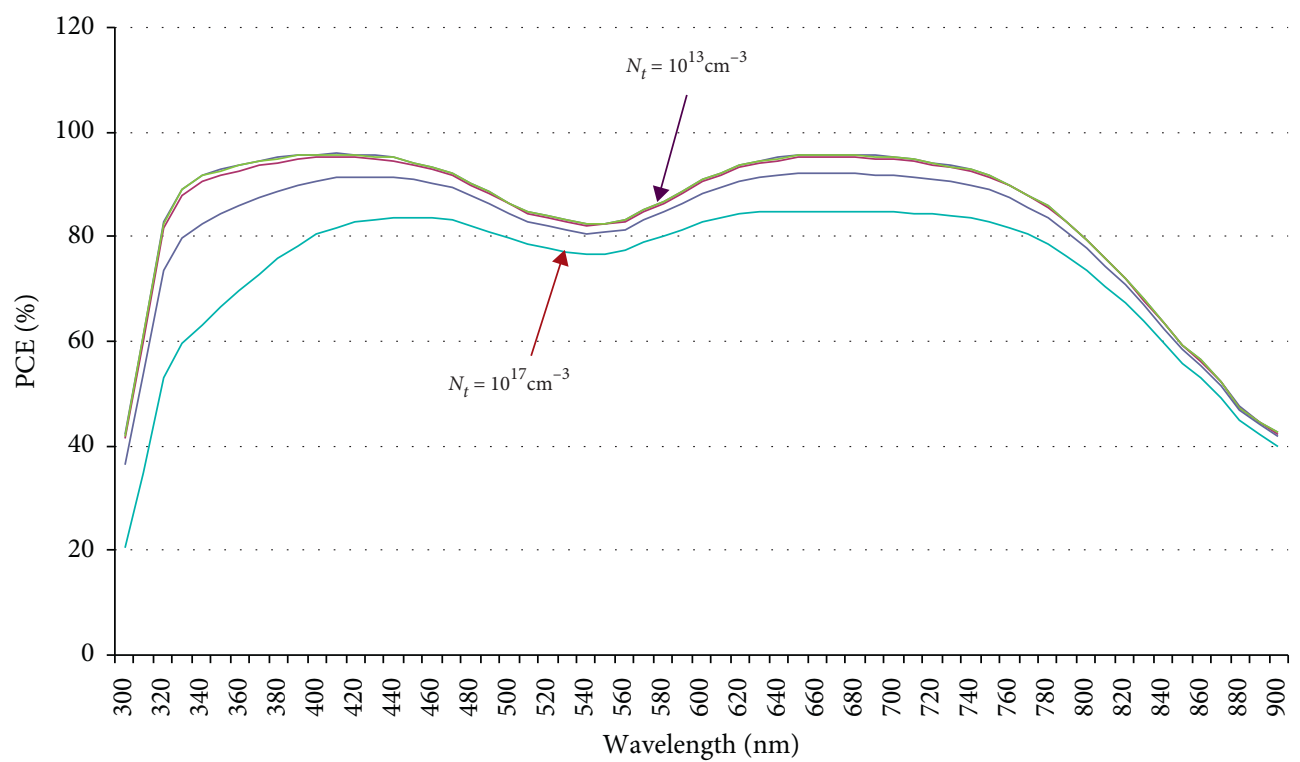

(a)

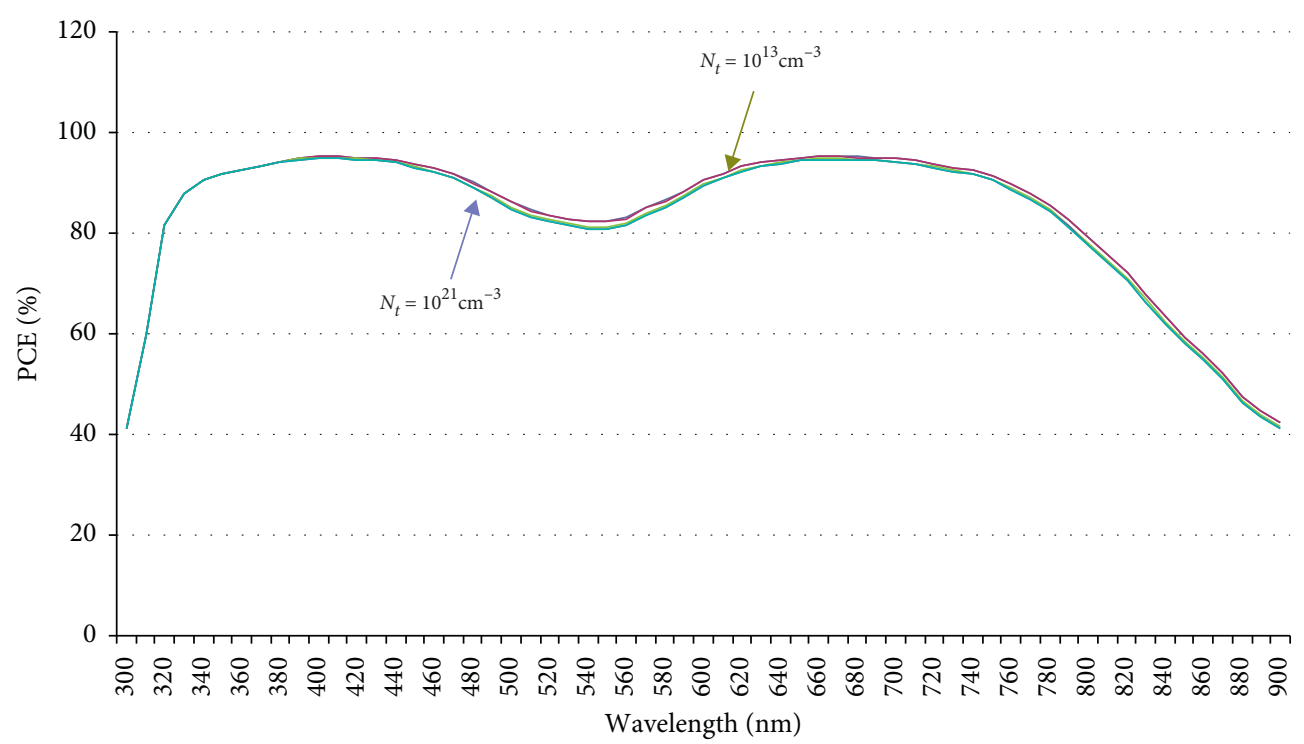

(b)

FIgURe 6: PCE curves of double PSCs with different defect densities of (a) ETM/perovskite interface IL1 and (b) perovskite/HTM interface IL2. 
TABLE 5: Device performance at different values of defect density.

\begin{tabular}{lcccc}
\hline$N_{t}\left(1 / \mathrm{cm}^{3}\right)$ & $\mathrm{V}_{\text {oc }}($ volt $)$ & $\mathrm{FF}(\%)$ & $\mathrm{Jsc}\left(\mathrm{mA} / \mathrm{cm}^{2}\right)$ & PCE $(\%)$ \\
\hline $1.00 E+13$ & 1.0705 & 84.30 & 33.05 & 29.82 \\
$1.00 E+14$ & 0.9999 & 83.76 & 33.04 & 27.67 \\
$1.00 E+15$ & 0.9388 & 80.73 & 32.95 & 24.98 \\
$1.00 E+16$ & 0.8889 & 71.98 & 32.22 & 20.62 \\
$1.00 E+17$ & 0.8660 & 65.12 & 29.36 & 16.56 \\
$1.00 E+18$ & 0.8619 & 65.77 & 27.42 & 15.54 \\
\hline
\end{tabular}

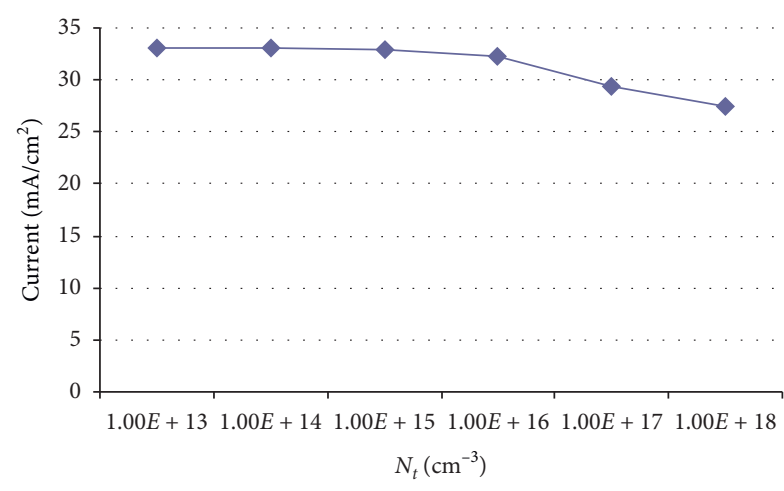

(a)

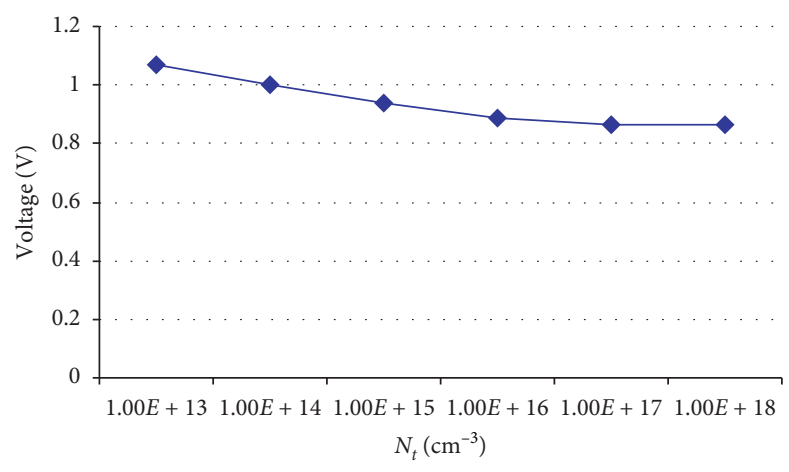

(c)

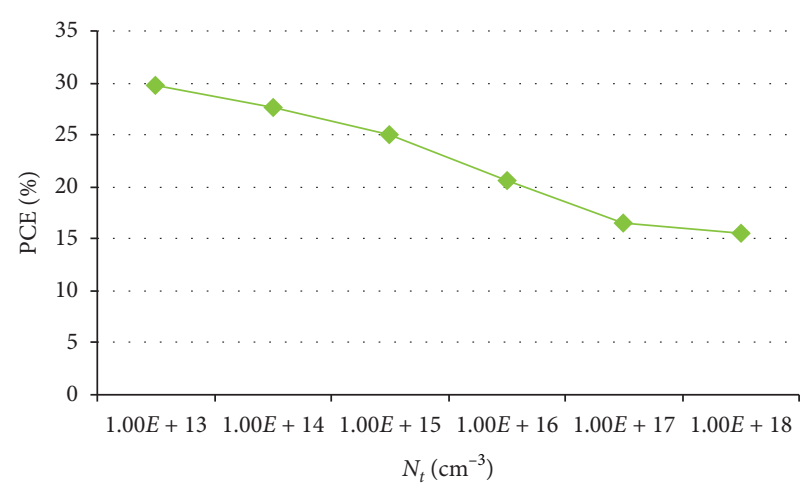

(b)

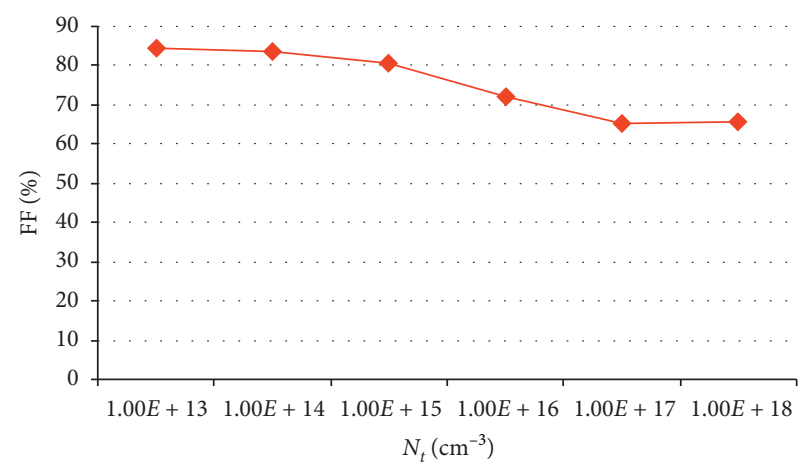

(d)

FIgURe 7: (a) Short-circuit current density as a function of defect density. (b) PCE as a function of defect density. (c) Open-circuit voltage as a function of defect density. (d) Fill factor as a function of defect density.

In this study, charge carrier mobility varied from $2 \times$ $10^{-3} \mathrm{~cm}^{2} \mathrm{~V}^{-1} \mathrm{~s}^{-1}$ to $20 \mathrm{~cm}^{2} \mathrm{~V}^{-1} \mathrm{~s}^{-1}$ to examine the influence on device performance as shown in Figure 8 and Table 6, and it is analyzed that best power conversion efficiency is achieved in mobility range of $2 \times 10^{-1}$ to $2 \mathrm{~cm}^{2} \mathrm{~V}^{-1} \mathrm{~s}^{-1}$. Figures 9 and 10 show the J-V characteristics and PCE curves of double copper-based PSC at different values of charge carrier mobility. In Voc/mobility graph, open-circuit voltage decreases with the increase in charge carrier mobility due to fall of internal power depletion that weakens the effect of a built-in electric field. If the carrier mobility is decreased, then short circuit current density decreases due to dissociation probability and scattering of charge carriers, leading to a decrease in energy conversion efficiency and fill factor. If the carrier mobility is increased, then the short-circuit current density increases because of better carrier transport at respective interfaces, leading to high efficiency and fill factor. Furthermore, an increase in mobility leads to a decrease in short circuit current density due to the extraction of charge carriers, reducing charge carrier density at a steady state. While in Voc/mobility graph, the open-circuit voltage decreases with the increase in charge carrier mobility due to fall of internal power depletion that weakens the effect of an electric field in the depletion region. The optimum efficiency of double PSC is obtained at carrier mobility of $2 \mathrm{~cm}^{2} \mathrm{~V}^{-1} \mathrm{~s}^{-1}$. 


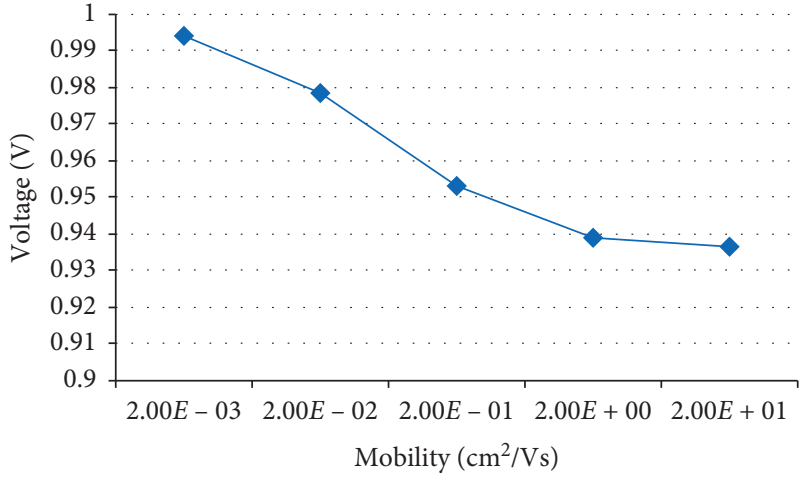

(a)

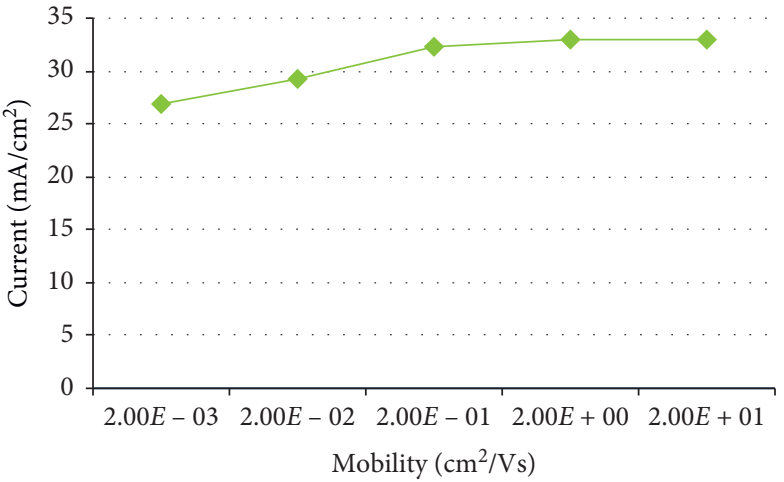

(c)

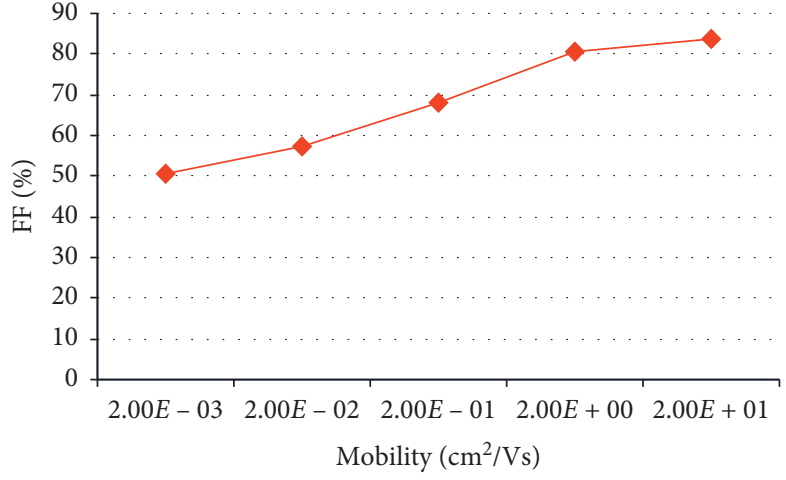

(b)

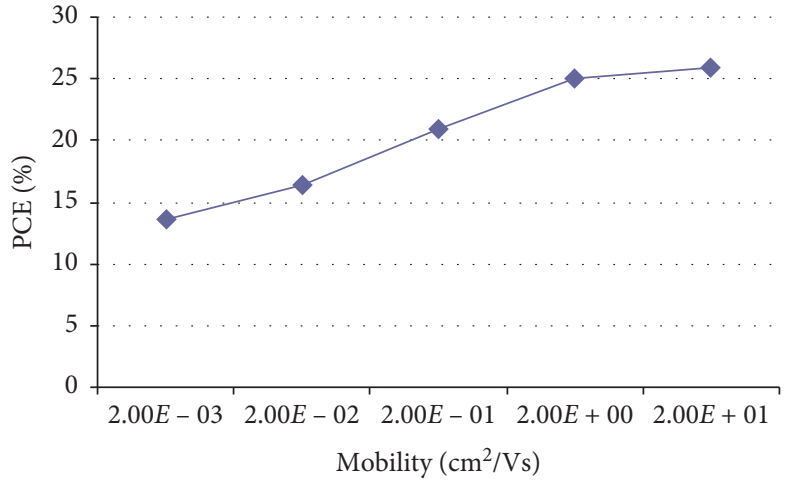

(d)

Figure 8: (a) Open-circuit voltage as a function of mobility. (b) Fill factor as a function of mobility. (c) Short-circuit current density as a function of mobility. (d) PCE as a function of mobility.

TABle 6: Device performance at different carrier mobilities.

\begin{tabular}{lcccc}
\hline Mobility $\left(\mathrm{cm}^{2} / \mathrm{Vs}\right)$ & Voc $($ volt $)$ & \% FF & Jsc $\left(\mathrm{mA} / \mathrm{cm}^{2}\right)$ & \\
\hline $2.00 E-03$ & 0.9940 & 50.76 & 26.83 & \\
$2.00 E-02$ & 0.9785 & 57.39 & 29.31 & 13.54 \\
$2.00 E-01$ & 0.9531 & 68.08 & 32.22 & 22.46 \\
$2.00 E+00$ & 0.9388 & 80.73 & 32.95 & 20.90 \\
$2.00 E+01$ & 0.9364 & 83.67 & 33.04 & 24.98 \\
\hline
\end{tabular}

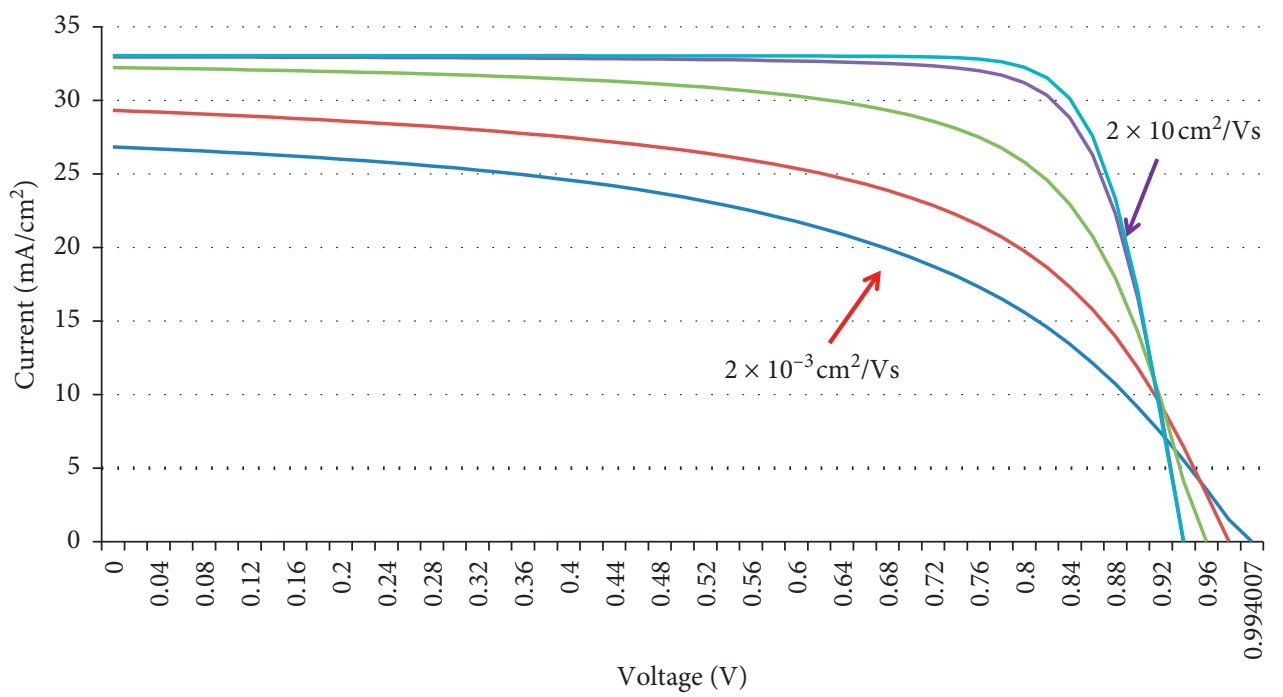

FIgURE 9: J-V curves of double PSCs with different carrier mobilities. 


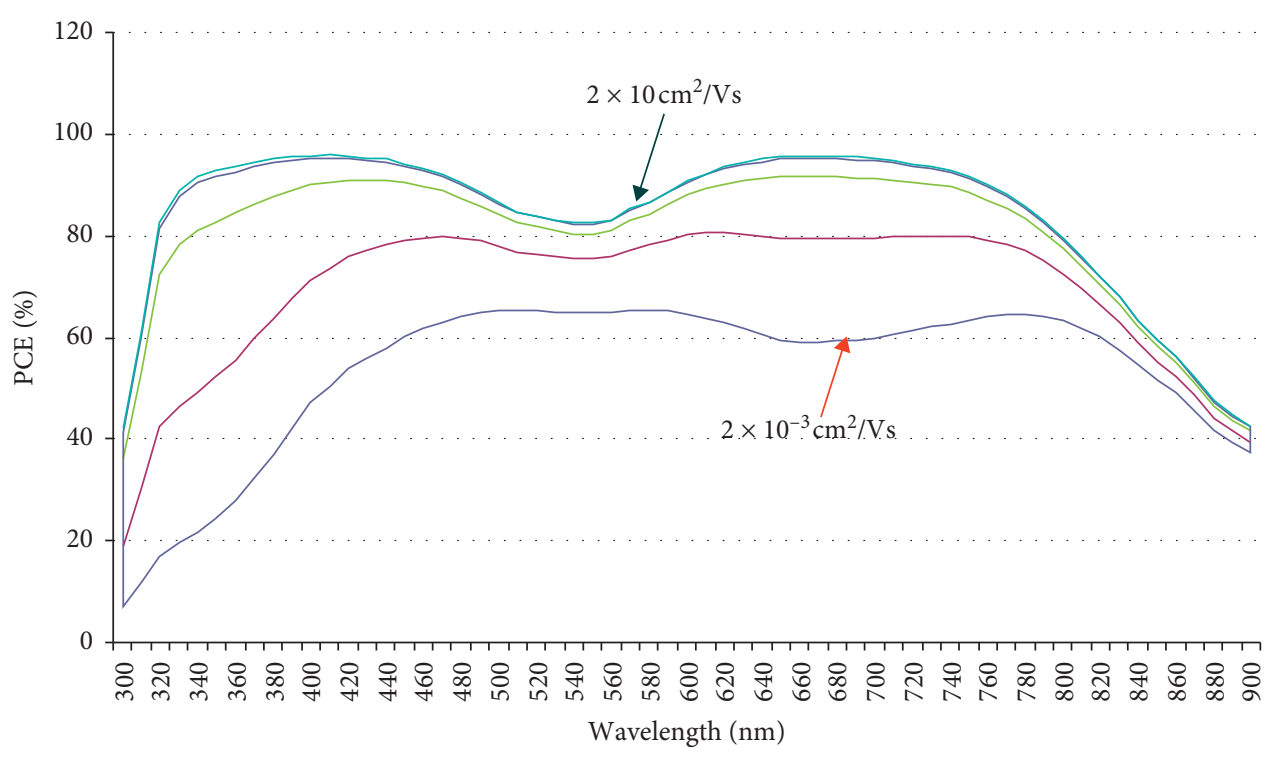

FIgURE 10: PCE curves of double PSCs with different carrier mobilities.

\section{Conclusion}

The organic-inorganic double perovskite solar cell structured as $\mathrm{FTO} / \mathrm{TiO}_{2} /(\mathrm{FA})_{2} \mathrm{BiCuI}_{6} /$ spiro-MeOTAD/Au was designed by the SCAPS device simulator. From the simulation, it is found that in the case of $(\mathrm{FA})_{2} \mathrm{BiCuI}_{6}$, the output parameters Jsc, Voc, PCE, and \%FF at absorber layer thickness $300 \mathrm{~nm}$ is $32.952 \mathrm{~mA} / \mathrm{cm}^{2}, 0.94 \mathrm{~V}, 24.98 \%$, and $80.73 \%$, compared with standard hybrid organic-inorganic perovskite performance under the same parameters. We analyzed that the hybrid organic-inorganic double perovskite would have the ability to replace $\mathrm{CH}_{3} \mathrm{NH}_{3} \mathrm{PbI}_{3}$ for next-generation lead-free harmless materials for perovskite solar cells and other optoelectronic applications. Furthermore, the influence of absorber layer thickness, defect density, and carrier mobility on device performance was studied. Moderate thickness minimized defects and moderate charge carrier mobility of the perovskite absorber layer show superior outcomes.

\section{Data Availability}

The data used to support the findings of this study are included within the article.

\section{Conflicts of Interest}

The authors declare that they have no conflicts of interest.

\section{Authors' Contributions}

G.A. Nowsherwan designed the research framework, collected data, performed simulations, interpreted the results, and wrote the manuscript. K. Jahangir co-wrote the manuscript and helped with equations and programs. S.S. Hussain and S. Riaz supervised and helped at each stage of the research in terms of analysis and optimization. Finally,
S. Naseem advised and performed a complete review of the research.

\section{Acknowledgments}

The authors are grateful to Professor Marc Burgelman for providing the SCAPS-1D simulation software in their simulations.

\section{Supplementary Materials}

The absorption coefficient data have been taken from different works of literature to make things easier for device simulation [35, 49-51]. (Supplementary Materials)

\section{References}

[1] A. Kojima, K. Teshima, Y. Shirai, and T. Miyasaka, "Organometal halide perovskites as visible light sensitizers for photovoltaic cells," Journal of the American Chemical Society, vol. 131, no. 17, pp. 6050-6051, 2009.

[2] J. H. Im, C. R. Lee, J. W. Lee, S. W. Park, and N. G. Park, “6.5\% efficient perovskite quantum-dot-sensitized solar cell," Nanoscale, vol. 3, pp. 4088-4093, 2011.

[3] M. Liu, M. B. Johnston, and H. J. Snaith, "Efficient planar heterojunction perovskite solar cells by vapour deposition," Nature, vol. 501, no. 7467, pp. 395-398, 2013.

[4] M. A. Green, A. Ho-Baillie, and H. J. Snaith, "The emergence of perovskite solar cell," Nature Photonics, vol. 8, no. 7, pp. 506-514, 2014.

[5] B. Conings, L. Baeten, T. Jacobs et al., "An easy to fabricate low temperature $\mathrm{TiO}_{2}$ electron collection layer for high efficiency planar heterojunction perovskite solar cells," $A P L$ Materials, vol. 2, no. 8, Article ID 081505, 2014.

[6] F. Aslan, H. Esen, and F. Yakuphanoglu, "Al/P-Si/Coumarin: $\mathrm{TiO} 2 / \mathrm{Al}$ organic-inorganic hybrid photodiodes: investigation of electrical and structural properties," Silicon, vol. 12, no. 9, pp. 2149-2164, 2019. 
[7] N. Cai, S.-J. Moon, L. Cevey-Ha et al., "An organic D- $\pi$-A dye for record efficiency solid-state sensitized heterojunction solar cells," Nano Letters, vol. 11, no. 4, pp. 1452-1456, 2011.

[8] N. Ahn, D. Y. Son, I. H. Jang, S. M. Kang, M. Choi, and N. G. Park, "Highly reproducible perovskite solar cells with average efficiency of $18.3 \%$ and best efficiency of $19.7 \%$ fabricated via Lewis base adduct of lead(II) iodide," Journal of the American Chemical Society, vol. 137, pp. 8696-8699, 2015.

[9] D. Liu and T. L. Kelly, "Perovskite solar cells with a planar heterojunction structure prepared using room-temperature solution processing techniques," Nature Photonics, vol. 8, no. 2, pp. 133-138, 2014.

[10] W. S. Yang, J. H. Noh, N. J. Jeon et al., "High performance photovoltaic perovskite layers fabricated through intramolecular exchange," Science, vol. 348, no. 6240, pp. 1234-1237, 2015.

[11] N. Anttu, "Shockley-Queisser detailed balance efficiency limit for nanowire solar cells," ACS Photonics, vol. 2, no. 3, pp. 446-453, 2015.

[12] W. E. I. Sha, X. Ren, L. Chen, and W. C. H. Choy, "Suppelmentary information for the efficiency limit of $\mathrm{CH}_{3} \mathrm{NH}_{3} \mathrm{PbI}_{3}$ perovskite solar cells," Applied Physics Letter, vol. 106, pp. 1-14, 2015.

[13] K. Tan, P. Lin, G. Wang, Y. Liu, Z. Xu, and Y. Lin, "Controllable design of solid-state perovskite solar cells by SCAPS device simulation," Solid-State Electronics, vol. 126, pp. 75-80, 2016.

[14] L. Lin, L. Jiang, Y. Qiu, and Y. Yu, "Modeling and analysis of HTM-free perovskite solar cells based on $\mathrm{ZnO}$ electron transport layer," Superlattices and Microstructures, vol. 104, pp. 167-177, 2017.

[15] N. Singh, A. Chaudhary, S. Saxena, M. Saxena, and N. Rastogi, "Electrical simulation of organic solar cell at different charge carrier mobility," IOSR Journal of Applied Physics, vol. 9, no. 2, pp. 01-04, 2017.

[16] U. Mandadapu, S. Victor Vedanayakam, and K. Thyagarajan, "Simulation and analysis of lead based perovskite solar cell using SCAPS-1D," Indian Journal of Science and Technology, vol. 10, no. 1, pp. 1-8, 2017.

[17] S. Zulqarnain Haider, H. Anwar, and M. Wang, "A comprehensive device modelling of perovskite solar cell with inorganic copper iodide as hole transport material," Semiconductor Science Technology, vol. 33, p. 12, 2018.

[18] A. Slami, M. Bouchaour, and L. Merad, "Numerical study of based perovskite solar cells by SCAPS-1D," International Journal of Energy and Environment (IJEE), vol. 13, pp. 17-21, 2019.

[19] G. C. Enebe, K. Ukoba, and T.-C. Jen, "Numerical modeling of effect of annealing on nanostructured $\mathrm{CuO} / \mathrm{TiO}_{2}$ pn heterojunction solar cells using SCAPS," AIMS Energy, vol. 7, pp. 527-538, 2019.

[20] M. Roknuzzaman, K. Ostrikov, H. Wang, A. Du, and T. Tesfamichael, "Towards lead-free perovskite photovoltaics and optoelectronics by ab-initio simulations," Scientific Reports, vol. 7, no. 1, Article ID 14025, 2017.

[21] M. Roknuzzaman, K. Ostrikov, K. Chandula Wasalathilake, C. Yan, H. Wang, and T. Tesfamichael, "Insight into lead-free organic-inorganic hybrid perovskites for photovoltaics and optoelectronics: a first-principles study," Organic Electronics, vol. 59, pp. 99-106, 2018.

[22] M. Burgelman, P. Nollet, and S. Degrave, "Modelling of polycrystalline semiconductor solar cells," Thin Solid Films, vol. 361-362, pp. 527-532, 2000.
[23] F. Liu, J. Zhu, J. Wei, Y. Li, M. Lv, S. S. Yang et al., "Numerical simulation: toward the design of high-efficiency planar perovskite solar cells," Applied Physics Letters, vol. 104, no. 25, Article ID 253508, 2014.

[24] M. Hirasawa, T. Ishihara, T. Goto, K. Uchida, and N. Miura, "Magneto absorption of the lowest exciton in perovskite-type compound $\mathrm{CH}_{3} \mathrm{NH}_{3} \mathrm{PbI}_{3}$," Physica B: Condensed Matter, vol. 201, pp. 427-430, 1994.

[25] Y. Wu, X. Yang, H. Chen, K. Zhang, C. Qin, J. J. Liu et al., "Highly compact $\mathrm{TiO}_{2}$ layer for efficient hole-blocking in perovskite solar cells," Applied Physics Express, vol. 7, no. 5, Article ID 052301, 2014.

[26] T. Minemoto and M. Murata, "Impact of work function of back contact of perovskite solar cells without hole transport material analyzed by device simulation," Current Applied Physics, vol. 14, no. 11, pp. 1428-1433, 2014.

[27] J. García-Cañadas, F. Fabregat-Santiago, H. J. Bolink, E. Palomares, G. Garcia-Belmonte, and J. Bisquert, "tion of electron and hole energy levels in mesoporous nanocrystalline $\mathrm{TiO}_{2}$ solid-state dye solar cell," Synthetic Metals, vol. 156, no. 14-15, pp. 944-948, 2006.

[28] M. M. Lee, J. Teuscher, T. Miyasaka, T. N. Murakami, and H. J. Snaith, "Efficient hybrid solar cells based on mesosuperstructured organometal halide perovskites," Science, vol. 338, no. 6107, pp. 643-647, 2012.

[29] M. Wang, C. Grätzel, S.-J. Moon et al., "Surface design in solid-state dye sensitized solar cells: effects of zwitterionic Coadsorbents on photovoltaic performance," Advanced Functional Materials, vol. 19, no. 13, pp. 2163-2172, 2009.

[30] J. H. Noh, S. H. Im, J. H. Heo, T. N. Mandal, and S. I. Seok, "Chemical management for colorful, efficient, and stable inorganic-organic hybrid nanostructured solar cells," Nano Letters, vol. 13, no. 4, pp. 1764-1769, 2013.

[31] D. Poplavskyy and J. Nelson, "Non-dispersive hole transport in amorphous films ofmethoxy-spirofluorene-arylamine organic compound," Journal of Applied Physics, vol. 93, no. 1, pp. 341-346, 2003.

[32] K. Wojciechowski, M. Saliba, T. Leijtens, A. Abate, and H. J. Snaith, "Sub- $150^{\circ} \mathrm{C}$ processed meso-superstructured perovskite solar cells with enhanced efficiency," Energy \& Environmental Science, vol. 7, no. 3, pp. 1142-1147, 2014.

[33] S. D. Stranks, G. E. Eperon, G. Grancini et al., "Electron-hole diffusion lengths exceeding 1 micrometer in an organo metal trihalide perovskite absorber," Science, vol. 342, no. 6156, pp. 341-344, 2013.

[34] H. J. Snaith and M. Grätzel, "Enhanced charge mobility in a molecular hole transporter via addition of redox inactive ionic dopant: implication to dye-sensitized solar cells," Applied Physics Letters, vol. 89, p. 2114, 2006.

[35] M. Roknuzzaman, C. Zhang, K. Ostrikov et al., "Electronic and optical properties of lead-free hybrid double perovskites for photovoltaic and optoelectronic applications," Scientific Reports, vol. 9, no. 1, p. 718, 2019.

[36] L. Huang, X. X. Sun, C. Li et al., "Electron transport layer-free planar perovskite solar cells: further performance enhancement perspective from device simulation," Solar Energy Materials and Solar Cells, vol. 157, Article ID 1038e1047, 2016.

[37] Z. Banyamin, P. Kelly, G. West, and J. Boardman, "Electrical and optical properties of fluorine doped tin oxide thin films prepared by magnetron sputtering," Coatings, vol. 4, no. 4, pp. 732-746, 2014.

[38] W. Abdelaziz, A. Zekry, A. Shaker, and M. Abouelatta, "Numerical study of organic graded bulk heterojunction solar 
cell using SCAPS simulation," Solar Energy, vol. 211, pp. 375-382, 2020.

[39] G. Rajan, K. Aryal, S. Karki, P. Aryal, and W. Robert, "Collins, and Sylvain Marsillac, Characterization and analysis of ultrathin CIGS films and solar cells deposited by 3-Stage process," Journal of Spectroscopy, vol. 2018, Article ID 8527491, 9 pages, 2018.

[40] M. T. Islam, M. R. Jani, A. F. Islam et al., "Investigation of CsSn0.5Ge0.5I3-on-Si tandem solar device utilizing SCAPS simulation," IEEE Transactions on Electron Devices, vol. 68, no. 2, pp. 618-625, 2021.

[41] G. Kartopu, B. L. Williams, V. Zardetto et al., "Data on dopant characteristics and band alignment of CdTe cells with and without a $\mathrm{ZnO}$ highly-resistive-transparent buffer layer," Data in Brief, vol. 22, pp. 218-221, 2019.

[42] F. Baig, Y. H. Khattak, B. M. Soucase, S. Beg, and N. A. K. Khani, "Efficiency limits of SnS thin film solar cells," Materials Focus, vol. 7, no. 6, pp. 807-813, 2018.

[43] S. Abdelaziz, A. Zekry, A. Shaker, and M. Abouelatta, "Investigating the performance of formamidinium tin-based perovskite solar cell by SCAPS device simulation," Optical Materials, vol. 101, Article ID 109738, 2020.

[44] L. Lin, L. Jiang, P. Li et al., "Simulated development and optimized performance of $\mathrm{CsPbI} 3$ based all-inorganic perovskite solar cells," Solar Energy, vol. 198, pp. 454-460, 2020.

[45] S. R. I. Biplab, M. H. Ali, M. M. A. Moon, M. F. Pervez, M. F. Rahman, and J. Hossain, "Performance enhancement of CIGS-based solar cells by incorporating an ultrathin $\mathrm{BaSi} 2$ BSF layer," Journal of Computational Electronics, vol. 19, no. 1, pp. 342-352, 2020.

[46] F. Ouédraogo, F. Zougmoré, and J. M. Ndjaka, "Numerical analysis of copper-indium-gallium-diselenide based solar cells by SCAPS-1D," International Journal of Photoenergy, vol. 2013, Article ID 421076, 45 pages, 2013.

[47] C.-H. Huang and W.-J. Chuang, "Dependence of parameters of CdTe solar cells on semiconductor properties studied by SCAPS-1D," Vacuum, vol. 118, pp. 32-37, 2015.

[48] A. S. Mathur, S. Dubey, N. B. P. Nidhi, and B. P. Singh, "Study of role of different defects on the performance of CZTSe solar cells using SCAPS," Optik, vol. 206, Article ID 163245, 2020.

[49] J. M. Ball, S. D. Stranks, M. T. Hörantner et al., "Optical properties and limiting photocurrent of thin-film perovskite solar cells," Energy \& Environmental Science, vol. 8, no. 2, pp. 602-609, 2015.

[50] J. Kischkat, S. Peters, B. Gruska et al., "Mid-infrared optical properties of thin films of aluminum oxide, titanium dioxide, silicon dioxide, aluminum nitride, and silicon nitride," $A p$ plied Optics, vol. 51, no. 28, pp. 6789-6798, 2012.

[51] M. Filipič, P. Löper, B. Niesen et al., " $\mathrm{CH}_{3} \mathrm{NH}_{3} \mathrm{PbI}_{3}$ Perovskite/ silicon tandem solar cells: characterization based optical simulations," Optics Express, vol. 23, p. A263, 2015.

[52] J. Burschka, N. Pellet, S.-J. Moon et al., "Sequential deposition as a route to high-performance perovskite-sensitized solar cells," Nature, vol. 499, no. 7458, pp. 316-319, 2013.

[53] H. Zhou, Q. Chen, G. Li et al., "Interface engineering of highly efficient perovskite solar cells," Science, vol. 345, no. 6196, pp. 542-546, 2014.

[54] M. Saliba, T. Matsui, J.-Y. Seo et al., "Cesium-containing triple cation perovskite solar cells: improved stability, reproducibility and high efficiency," Energy \& Environmental Science, vol. 9, no. 6, pp. 1989-1997, 2016.

[55] B. Chen, Y. Bai, Z. Yu et al., "Efficient semitransparent perovskite solar cells for $23.0 \%$-efficiency perovskite/silicon four-terminal tandem cells," Advanced Energy Materials, vol. 6, no. 19, 19 pages, Article ID 1601128, 2016.

[56] G. E. Eperon, V. M. Burlakov, P. Docampo, A. Goriely, and H. J. Snaith, "Morphological control for high performance, solution-processed planar heterojunction perovskite solar cells," Advanced Functional Materials, vol. 24, no. 1, pp. 151-157, 2014. 